\title{
The Analysis of Stock Market Development Indicators: Evidence from the ASEAN-5 Equity Markets
}

\author{
Pariyada Sukcharoensin and Sorasart Sukcharoensin
}

\begin{abstract}
This paper proposes indicators to assess the development of the stock markets in ASEAN-5 countries, namely Indonesia, Malaysia, the Philippines, Singapore and Thailand. The results show the distinctions among these equity markets. The indicators in this research separate these stock markets into two tiers. The results indicate that SGX, SET, and BM have higher level of development comparing to other stock markets in the same region. Their main strengths are in their accessibility. SGX has higher level of development in most aspects, specifically in size when measured by market capitalization. BM gains its advantage on access dimension. SET is outstanding in stability dimension. The other group is IDX and PSE. The latter equity markets need to improve in most aspects. These findings convey important messages to less-developed stock markets to establish the well-planned strategy and policy to build up the development before full participation of ASEAN Economic Community in 2015.
\end{abstract}

Index Terms-ASEAN economic community, equity market, market development indicator, stock market development.

\section{INTRODUCTION}

The ASEAN has been a regional economic integration which was initiated in 1967. This collaboration aims to increase the potential of bargaining in the global, and share resources among members in this region. The cooperation has been started by ASEAN Free Trade Area (AFTA) initiating in 1993. In 2009, the ASEAN step forward to ASEAN Economic Community (AEC) for establishing market base and working together to strengthen in the region. The initiation of ASEAN Exchanges linkage between seven stock markets from six countries in ASEAN has been established. This includes stock market of Thailand, Malaysia, Indonesia, Philippine, Singapore, Ho Chi Min, and Hanoi, hope to make the expediency for funding and investment in the region. There are 3,613 companies listed in seven stock markets. Total stock market value is $1,980.37$ billion USD or eighth ranked in the world, as in [1] Therefore, understanding the development of stock markets among this emerging countries within this region become more interesting in global investor's perspective.

In this study, we propose a set of indicators to measure the development level of the ASEAN-5 equity markets, which are the Stock Exchange of Thailand (SET), the Singapore Exchange (SGX), Bursa Malaysia (BM), the Indonesia Stock

Manuscript received June 20, 2013; revised August 26, 2013. This work was supported in part by the National Research Council of Thailand.

Pariyada Sukcharoensin and Sorasart Sukcharoensin are with the Graduate School of Development Economics, the National Institute of Development Administration, Klongchan, Bangkapi, Bangkok, 10240 Thailand (e-mail: pariyada.s@nida.ac.th, sorasart@nida.ac.th).
Exchange (IDX), and the Philippine Stock Exchange (PSE). The findings are useful for public and private sectors involved in the development and policy making to promote funding and investment efficiency among these stock markets. More importantly, the results shed lights on the well-planned development strategy and policy to build up the competitive advantage of each stock market.

\section{LITERATURE REVIEW}

Previous works on developing indicators to assess the development of stock markets have focused on disaggregating data to understand trends and development in individual equity market. Analysts equipped with disaggregated data would focus on one aspect at a time to study the issue of stock market development. Most of the studies use the ratio of market capitalization to GDP, the ratio of total value of shares traded to GDP, or the ratio of total value of shares traded to market capitalization as measures for stock market development (for example, [2]-[5]). Stock market capitalization is a measure of both the stock market's ability to allocate capital to investment projects and its ability to provide significant opportunities for risk diversification for investors. The ratio of total value of shares traded to GDP and the ratio of total value of shares traded to market capitalization are indicators of market liquidity. The former measures the ability to trade economically significant positions on the stock market, and the latter is an indicator of liquidity of assets traded on the market, not adjusted for the size of the market relative to the economy, as in [6]-[7].

These variables are only good proxies for size, a general development perspective of the market. Since the size of the market focus on only one dimension, so the assessments are not taking into account other elements of the development. The World Bank Economic Review also dedicates its May 1996 issue to the role of the stock markets in economic growth. The Financial Sector Development Indicators (FSDI) project was established to set up a new perspective to look at stock market development. The project aims to be the first dock of call for statistics and analytical tools to evaluate financial sector. The FSDI project employs several variables covering banking systems, capital markets, non-bank financial sectors, the accessibility to finance, as well as institutional environments. The project strong point is to provide ability for comprehensiveness, yet retains flexibility for customized assessments. The FSDI harbors capacity to pool the multitude dimensions of a financial sector-size, access, efficiency and stability - with traditional financial sub-sectors, such as banking, capital markets, etc.

Since stock markets are multi-dimensional, to assess their 
development have to go beyond size. In this study, we believe that only size of the equity is insufficient to measure the level of development of the stock markets. Therefore, we apply the FSDI's framework to assess stock market development with our additional extended dimensions. This framework considers four aspects of stock market development such as size, access, efficiency and stability. The details are shown in Fig. 1.

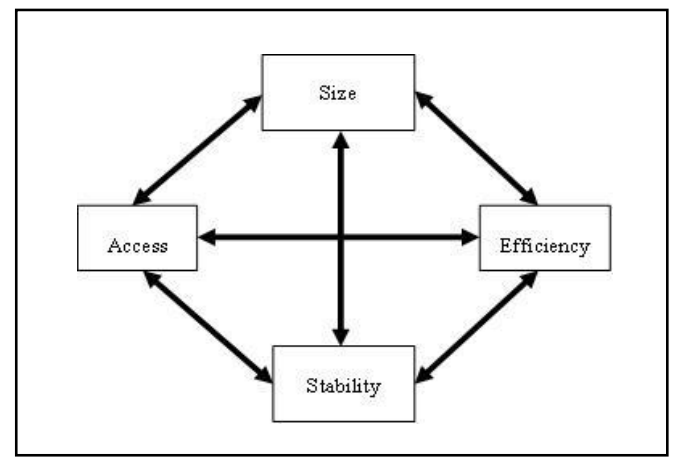

Fig. 1. The Financial Sector Development Indicators (FSDI).

Larger equity market provides an important source of investment capital at relatively low costs, as in [8]. A more developed equity market also provides a variety product that lowers the cost of capital that is essential for development. Therefore, size of the market as measured by market capitalization, the ratio of market capitalization to GDP, volume and value traded, is an important indicator of market development.

The development of the stock market also critically depends on accessibility for investors and firms to access to the market. Less concentration of top firms in market is preferred for a well-develop market. This means not only large firms, but also small companies can raise fund and compete fairly in the market. Therefore, the access dimension of the stock market development is measured by number of listed firms, number of newly IPO (during 2012), concentration ratio or the sum of market share of largest 10 firms in term of market capitalization, and the Herfindahl-Hirschman index (HHI). High HHI determines if a monopoly exists.

The third dimension is efficiency. A well-developed stock market should provide the opportunity for investors and participants to allocate capital to productive investments efficiently. A more efficient stock market should have low degree of co-movement of individual stocks with the market. Also, to be efficient, stock price should have high frequent price movement as reflect in low transaction cost. Thus, we use four variables as a proxy for efficiency, namely average total trading cost, percentage of stocks having autocorrelation and having zero returns. Lastly, R-squared, the measure of stock price synchronicity, to measure the degree of co-movement of individual stocks with the market.

Theoretically, the presence of stock markets would mitigate the principal agent problem and reduce asymmetry information, thus promoting stability and long-term growth, as in [9]. Given that the stock price at any time is mirror of firm performance, weakening corporate governance would be reflected tendency to manipulate earnings of the firms to window dressing its performance. In a well-functioning stock market, this behavior should be minimal. Moreover, to be stable, stock returns should distribute normal and the market should have less skewed as well. Also, the percentage of earning manipulation is an indicator to measure the market stability. The more companies manipulate its earning, the less stable the financial market. We also consider average financial information such as Price to earnings ratio, Price to book ratio, and dividend yield to be part of stability.

\section{Methodology}

This study collected the data from various sources. The data collection includes synthesizing information already being collected by international and national organizations. The data are synthesized from the Global Competitiveness Report in the year 2012 presented by [10]-[11]. For stock market information, we collect from the stock market database of each country, the World Federation of Exchanges database, Compustat and Datastream database between 2007-2012. We use guidelines proposed by [12] to describe and compute the relative value of subcategories under each development indicator among ASEAN-5 stock markets. The relative value of each indicator for assessment of stock market development among 5 nations can be done by using equation (1).

$$
C_{A, i}=\frac{\left(\text { Value }_{A . i}-\operatorname{Min}_{A}\right)}{\left(\operatorname{Max}_{A}-\operatorname{Min}_{A}\right) / 10}
$$

where $C_{A, i}$ is the relative value of factor $A$ for stock market $i$; Value $_{A, i}$ is the numeric value of factor $A$ for stock market i; $\operatorname{Min}_{A}$ is the minimum value of factor $A$ among all stock markets; $\operatorname{Max}_{A}$ is the maximum value of factor $A$ among all stock markets; 10 is the graph scale full points to compare among stock markets; and $i$ is the stock markets in this analysis which are SGX, SET, BM, PSE, and IDX.

In principle, a well-developed stock market should theoretically perform better than a less-developed equity market in all dimensions. Therefore, we hypothesize that the cumulated overall relative value for a more developed country should have higher value than less developed countries.

\section{RESUlts}

The development of stock markets among ASEAN-5 nations is analyzed in this section. The analysis considers four aspects of stock market development including 1) Size, 2) Access, 3) Efficiency, and 4) Stability. To illustrate the results, Table I shows that mean score of the four stock market development indicators among ASEAN-5 nations. Overall, the SGX holds the first rank (Overall score $=27.52$ ), then the SET (Overall score $=25.14$ ), the BM (Overall score $=23.38)$. Whereas the IDX (Overall score $=14.49$ ) and PSE (Overall score $=11.46$ ) are the fourth and the fifth ranked, respectively. The details are shown in Table I. 
TABLE I: STOCK MARKET DEVELOPMENT INDICATORS

\begin{tabular}{|c|c|c|c|c|c|c|}
\hline \multirow{2}{*}{ Dimension } & \multicolumn{5}{|c|}{ Score $(0-10)$} & \multirow{2}{*}{ Remark } \\
\hline & Indonesia & Malaysia & Philippines & Singapore & Thailand & \\
\hline \multicolumn{7}{|l|}{ Size } \\
\hline -Mkt. Cap & 3.7 & 4.4 & 0.0 & 10.0 & 3.0 & World Federation Exchange 2012 \\
\hline -Mkt/GDP & 0.0 & 5.0 & 1.4 & 10.0 & 1.5 & World Bank 2012 \\
\hline -Volume of share trading & 7.2 & 0.0 & 0.8 & 3.7 & 10.0 & DataStream 2012 \\
\hline -Value of share trading & 2.8 & 3.7 & 0.0 & 10.0 & 6.9 & DataStream 2012 \\
\hline Average scores & 3.43 & 3.30 & 0.53 & 8.41 & 5.35 & \\
\hline \multicolumn{7}{|l|}{ Access } \\
\hline -Companies Listed & 3.0 & 10.0 & 0.0 & 7.8 & 4.4 & World Federation Exchange 2012 \\
\hline -Newly list companies (2012) & 10.0 & 6.7 & 0.0 & 9.4 & 7.2 & World Federation Exchange 2012 \\
\hline$-\mathrm{CR}-10$ & 0.7 & 7.1 & 0.7 & 10.0 & 0.0 & Calculated from Compustat 2012 \\
\hline -HHI-Mkt cap & 2.9 & 10.0 & 0.0 & 2.9 & 4.3 & Calculated from Compustat 2012 \\
\hline Average scores & 4.1 & 8.5 & 0.2 & 7.5 & 4.0 & \\
\hline \multicolumn{7}{|l|}{ Efficiency } \\
\hline -Average total cost $(\mathrm{Bp})$ & 5.7 & 9.7 & 0.0 & 10.0 & 7.2 & The Elkins/Mcsherry Global Trading Cost Analysis Report 2012 \\
\hline$-\%$ of companies with autocorrelation & 10.0 & 4.9 & 6.3 & 0.0 & 8.2 & Calculated from DataStream 2012 \\
\hline -Zero return $(\%)$ & 3.5 & 4.5 & 9.4 & 0.0 & 10.0 & Calculated from DataStream 2012 \\
\hline -Synchronity (R-square) & 1.9 & 6.3 & 5.9 & 10.0 & 0.0 & Calculated from DataStream 2012 \\
\hline Average scores & 5.3 & 6.4 & 5.4 & 5.0 & 6.3 & \\
\hline \multicolumn{7}{|l|}{ Stability } \\
\hline -SKEW & 6.3 & 0.0 & 10.0 & 9.6 & 9.5 & Calculated from DataStream 2012 \\
\hline -Manipulation Earning (\% of Companies) & 0.0 & 9.7 & 9.7 & 0.0 & 10.0 & Calculated from Compustat 2012 \\
\hline \multicolumn{7}{|l|}{-Fundamental information } \\
\hline PE ratio & 1.4 & 3.5 & 0.0 & 9.6 & 10.0 & Calculated from DataStream 2012 \\
\hline PB ratio & 0.0 & 7.3 & 7.0 & 10.0 & 7.9 & Calculated from DataStream 2012 \\
\hline DY & 0.5 & 5.9 & 0.0 & 3.7 & 10.0 & Calculated from DataStream 2012 \\
\hline Average scores & 1.6 & 5.3 & 5.3 & 6.6 & 9.5 & \\
\hline Overall scores & 14.49 & 23.38 & 11.46 & 27.52 & 25.14 & \\
\hline
\end{tabular}

Comparing size dimension of the equity market between 5 countries, SGX earns the highest level of development in term of market capitalization relative to its economy and value of share trading. The average relative value for size dimension of SGX is far beyond other equity market in the region with an average relative value of 8.41 , followed by SET, IDX, BM, and PSE, with average relative value for size of $5.35,3.43,3.3$, and 0.53 respectively.

Considering the access dimension, BM gains its competitiveness in providing opportunity for firms to raise capitals in the stock exchange. The average relative value for access dimension of BM is 8.50, closely followed by SGX with an average relative value of 7.50 . These two equity markets are less concentrated and has a large number of newly companies listed on the exchanges. SET and IDX have moderate average relative value of 4.0 for access dimension. However, PSE needs to be improved for small companies to get access to equity market.

Details of efficiency dimension are found and all equity market in this region has relatively similar level of efficiency. SGX is the lead in terms of low trading costs and low com-movement of individual stock returns relative to the market. IDX and SET have strengths on their less proportion of firms that are correlated to the market.

Regarding to stability dimension, SET has highest average score in this dimension, followed by SGX, BM, PSE, and IDX. The SET takes a lead in low P/E ratio and high dividend yield compared to other equity markets in the region, while IDX loses its ground in all aspects.

Next, we describe the level of stock market development using area within each equity market's diamond. Different shape of a diamond illustrates the overall different in each dimension of stock market development. We can separate the diamond of ASEAN-5 equity markets into two groups according to their relative position in each dimension. The first set is composed of IDX and PSE as shown in Fig. 2.

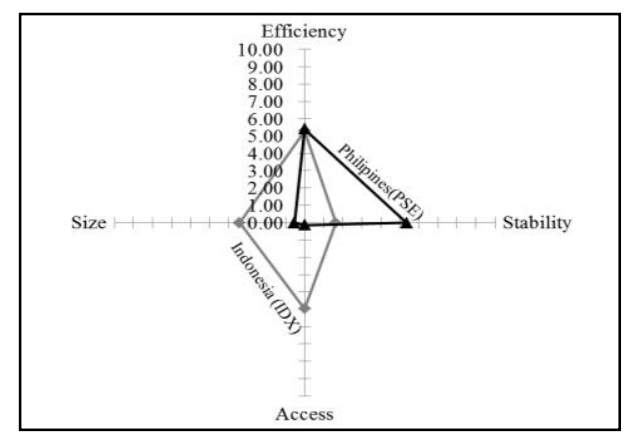

Fig. 2. The four dimension of the Stock market development indicators of IDX and PSE.

From the figure, we can see that PSE has to improve on its access and size dimension comparing to IDX. Only stability dimension of PSE is superior to its counterparts, IDX.

The second group is comprised of SGX, SET, and BM. Fig. 3 illustrates the graphical presentation of the four dimensions in assessing the stock market development indicators. SGX signifies the highest level of development. This is due to the strongest dimension in size and relatively strong in access and stability dimension. SGX holds the top position for size dimension. The access of the SGX is in the second position of the analyzed equity markets; followed BM. BM has its strength in high efficiency and access dimension. SET has its strength in stability and efficiency, but need to improve its access dimension.

The areas under the graph for all stock market development dimensions are calculated and compare among countries in this region. SGX has the highest stock market development among ASEAN-5 as demonstrated in Fig. 4, followed by SET, BM, and IDX, and whereas PSE was the lowest ranked in overall dimensions. 


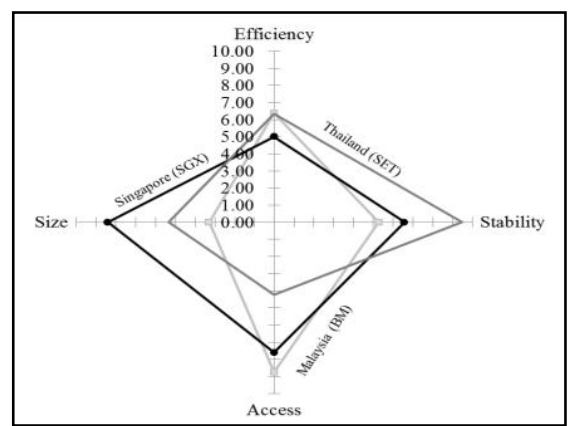

Fig. 3. The four dimension of the Stock market development indicators of SGX, BM and SET.

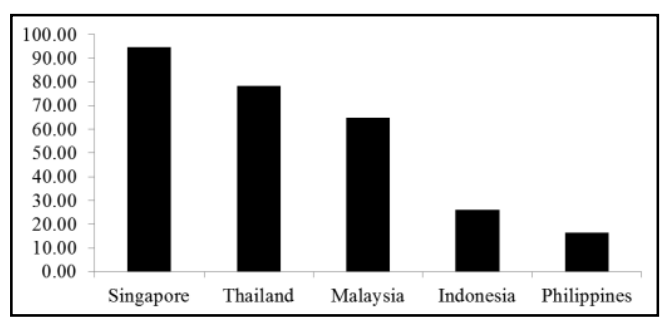

Fig. 4. The area under the graph for all dimensions among ASEAN-5 equity markets.

\section{CONCLUSION}

This study analyzes the stock market development indicators among ASEAN-5 equity markets. We apply the FSDI's framework to assess stock market development. This framework considers four aspects of stock market development including size, access, efficiency and stability. The analysis based on these four dimensions separate these stock markets into two groups. The well-developed equity markets are the SGX, SET, and BM. Overall, there is a high tendency that after full participation of ASEAN Exchange, SGX will take the lead. However, efficiency is its major pullbacks. BM has high level of development close to SGX. SET has high potential to move from its current position as it has highest score in stability aspect. BM has built on its accessibility since it has highest number of listed firms and least concentrated market. However, the volume and turnover rate of BM is low. IDX has advantage in size and number of listed firms, while its weaknesses are efficiency and stability. PPE is ranked lowest in most aspects and needed to improve its current status to achieve higher level of stock market development.

\section{REFERENCES}

[1] World Federation of Exchanges. (February 2013). WFE 2012 market highlights. [Online]. Available: http://www.world-exchanges.org/files/statistics/2012\%20WFE\%20M arket\%20Highlights.pdf

[2] M. Pagano, "Financial markets and growth: An overview," Eupropean Economic Reviews, vol. 37, no. 2-3, pp. 613-622, 1993.

[3] A. Demirguc-Kunt and R. Levine, "Stock market development and Financial Intermediaries: Stylized Facts," The World Bank Economic Review, vol. 10, no. 2, pp. 291-321, 1996.

[4] B. Thorsten and R. Levine, "Stock markets, banks, and growth: panel evidence," Journal of Banking and Finance, vol. 28, pp. 423-442, 2003.

[5] B. Seetanah and S. Ramessur, "Financial development and economic growth," Journal of Economic Studies, vol. 36, no. 2, pp. 124-134, 2008.
[6] R. Levine and S. Zervos, "Stock markets, banks, and economic growth," American Economic Review, vol. 88, no. 3, pp. 537-58, 1998.

[7] V. F. Garcia and L. Liu, "Macroeconomic determinants of stock market development," Journal of Applied Economics, vol. 2, no. 1, May 29-59, 1999.

[8] M. Dailami and M. Atkin, "Stock markets in developing countries: key issues and a research agenda," Policy Research Working Paper Series 515, The World Bank, 1990.

[9] C. Adjasi and N. Biekpe, "Stock market development and economic growth: the case of selected African countries," African Development Review, vol. 18, pp. 144-161, April 2006.

[10] World Economic Forum. (December 2012). Global Competitiveness Report 2012-2013. [Online]. Available: http://www3.weforum.org/docs/WEF_GlobalCompetitivenessReport_ 2012-13.pdf

[11] International Institute for Management Development, IMD World Competitiveness Yearbook 2012, Lausanne, Switzerland: IMD, 2012.

[12] H. B. J. Stone and A. Ranchhod. (2006). Competitive advantage of nation in the global arena: A quantitative advancement to Porter's diamond applied to the UK, USA and BRIC nations. Strategic Change. [Online]. 15. pp. 283-294. Available: http://www.relooney.info/ 0_New_12638.pdf

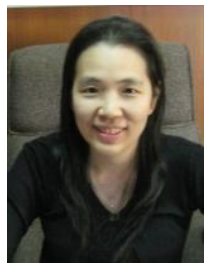

Pariyada Sukcharoensin was born in Bangkok, Thailand. She received her doctoral degree in finance from Thammasat University. Previously, she worked with the Stock Exchange of Thailand (SET). She is now a full-time lecturer at the Graduate School of Development Economics, National Institute of Development Administration (NIDA) and also a visiting lecturer for many graduate programs. Further, she is the exam committee of the securities analyst program for investment professionals. She is an author of the chapters about derivatives market in the books published by the Stock Exchange of Thailand and Thammasat Business School.

Dr. Sukcharoensin had participated in conducting the Master Plan for Thailand's Capital Markets proposed to the Minister of Finance. She had also engaged in the project funded by the Thailand Research Fund (TRF). Her academic experiences also include various working papers in finance and the presentations at the top international conferences in the USA and Asia. She had received the best research paper awards from the National Research Council of Thailand (NRCT) and the Capital Market Research Institute (CMRI), the Stock Exchange of Thailand. Her research interests include risk management, derivatives, portfolio management, financial econometrics, corporate finance, and personal finance.

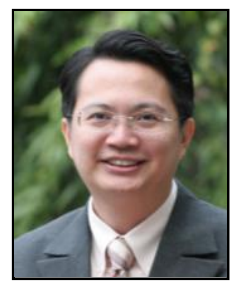

Sorasart Sukcharoensin was born in Bangkok, Thailand. He earned his doctoral degree in finance from Thammasat University. Currently, he is an associate dean for academic affairs at the Graduate School of Development Economics at the National Institute of Development Administration (NIDA). He is an author of the article on the role of debt in good governance published by the Thai Bond Dealing Centre (ThaiBDC).

Dr. Sukcharoensin had been the project supervisor and consultant to the corporate governance project of the Thai Institute of Directors (IOD), the Stock Exchange of Thailand (SET), and Sasin Graduate Institute of Business Administration. He had also engaged in many research projects funded by the National Research Council of Thailand (NRCT), the Thailand Research Fund (TRF), the Small Business Credit Guarantee Corporation (SBCG), and the Student Loans Fund. He had received a professional trainer award from the Stock Exchange of Thailand and achieved the Rajapruk award for teaching excellence from the National Institute of Development Administration. His research interests include capital market development, corporate governance, corporate finance, derivatives, insider trading, market microstructure, and securities analysis. 